\title{
Financial caps for oil pollution damage: a historical mistake?
}

Citation for published version (APA):

Faure, M. G., \& Wang, H. (2008). Financial caps for oil pollution damage: a historical mistake? Marine Policy, 32(4), 592-606. https://doi.org/10.1016/j.marpol.2007.10.008

Document status and date:

Published: 01/01/2008

DOI:

10.1016/j.marpol.2007.10.008

Document Version:

Publisher's PDF, also known as Version of record

Document license:

Taverne

Please check the document version of this publication:

- A submitted manuscript is the version of the article upon submission and before peer-review. There can be important differences between the submitted version and the official published version of record.

People interested in the research are advised to contact the author for the final version of the publication, or visit the DOI to the publisher's website.

- The final author version and the galley proof are versions of the publication after peer review.

- The final published version features the final layout of the paper including the volume, issue and page numbers.

Link to publication

\footnotetext{
General rights rights.

- You may freely distribute the URL identifying the publication in the public portal. please follow below link for the End User Agreement:

www.umlib.nl/taverne-license

Take down policy

If you believe that this document breaches copyright please contact us at:

repository@maastrichtuniversity.nl

providing details and we will investigate your claim.
}

Copyright and moral rights for the publications made accessible in the public portal are retained by the authors and/or other copyright owners and it is a condition of accessing publications that users recognise and abide by the legal requirements associated with these

- Users may download and print one copy of any publication from the public portal for the purpose of private study or research.

- You may not further distribute the material or use it for any profit-making activity or commercial gain

If the publication is distributed under the terms of Article $25 \mathrm{fa}$ of the Dutch Copyright Act, indicated by the "Taverne" license above, 


\title{
Financial caps for oil pollution damage: A historical mistake?
}

\author{
Michael Faure ${ }^{\mathrm{a}}$, Wang Hui ${ }^{\mathrm{b}, *}$ \\ ${ }^{a}$ Maastricht University, Faculty of Law, Metro, P.O. Box 616, 6200 MD Maastricht, The Netherlands \\ ${ }^{\mathrm{b}}$ Institute of Environmental and Energy Law, Catholic University of Leuven, Law Faculty, Tiensestraat 41, 3000 Leuven, Belgium
}

Received 25 March 2007; accepted 29 October 2007

\begin{abstract}
The limitation of liability (known as financial caps) of the ship owner has a long tradition in maritime law in general and in the marine oil pollution compensation regime in particular. This paper uses the economic instrument to critically analyze such a mechanism, in order to answer the question if the financial caps are indeed a historical mistake.

(C) 2007 Elsevier Ltd. All rights reserved.
\end{abstract}

Keywords: Strict liability; Limitation of liability; Financial caps; Civil Liability Convention (CLC); Fund Convention; The (IOPC) Fund; Unilateral accident; Bilateral accident; Deterrence; path dependency; Interest group

\section{Introduction}

Recent years have witnessed the occurrence of a great many oil spills in Europe, and other parts of the world. The names Torrey Canyon, Amoco Cadiz etc. refer to the major incidents that occurred in the 1960s and 1970s. Shortly after the Torrey Canyon incident an international convention on civil liability for oil pollution damage of 1969 was promulgated together with an additional fund convention in 1971. These conventions had the alleged goals of guaranteeing some compensation to the victims of oil pollution damage. A strict liability was imposed on the tanker owner, but at the same time the liability was channelled to him. This means that no party other than the tanker owner can be held liable for the pollution damage. In addition strict limits on liability applied, the so-called financial caps.

Meanwhile new accidents, also in the United States (with the Exxon Valdez), made clear that the international regime, as it had been established at the end of the 1960s, could not provide compensation in a satisfactory way. Even more recently new incidents again hit the coasts of Europe, more particularly with the Erika (off the coast of Brittany-France) in 1999 and the Prestige (off the coast of Galicia-Spain) in

\footnotetext{
${ }^{*}$ Corresponding author. Tel.: + 32486729285 .

E-mail addresses: Michael.Faure@FACBURFDR.unimaas.nl (M. Faure), appleandhui@yahoo.com (H. Wang).
}

2002. As a result of these ever-increasing incidents, always new amendments to the international conventions were adopted in order to increase the amounts of liability. Recently, in 2003, a supplementary fund was established to provide a so-called third tier of compensation in addition to the Civil Liability Convention (CLC) and the existing international oil pollution compensation fund.

Notwithstanding all these adaptations of the conventions with ever new amendments, still the question arises why the damage caused by oil spills is dealt with in a totally different way to traditional damage. Indeed, as was mentioned above, the regime in the international oil pollution conventions differs quite substantially from traditional tort law in most legal systems. This is more particularly the case for the so-called channelling, which means that not all parties involved in oil pollution incidents are held liable, but that the liability is (often exclusively) directed to the tanker owner under the conventions. Also the fact that liability is capped to a certain amount of course constitutes a serious deviation from traditional tort law.

In that respect many important questions arise, some of which we would like to tackle in this paper. First of all the question arises why, in a historical perspective, financial caps were introduced in maritime law in general, but in the oil pollution conventions in particular. Indeed, the financial caps in maritime law in general have already been referred to as 'an anachronism' in the literature [1], 
however, less attention has been paid to the consequences of applying these traditional financial caps of maritime law to damage caused by oil pollution. Hence, it seems necessary to conduct a basic legal historical analysis of the documents preceding the conventions to examine the precise reasons for the mentioned deviations (more particularly the financial caps). Of course, when addressing this legal history, the question will inevitably also come up whether particular interest groups may have lobbied in favor of these deviations.

In addition, the question arises how these financial caps can be viewed from a law and economics perspective. The traditional economic analysis of law can thus be used to critically analyze the limitation of liability. When the economic analysis points at the possible inefficiency of the financial caps, again the legal history will be used to examine why these inefficiencies were introduced in the international conventions at the time.

The paper thus follows different methodological approaches: both traditional economic analysis of accident law and interest group analysis will be followed as well as a legal historical perspective, more particularly to find out the formal reasons given for the introduction of financial caps and channelling and to identify a possible influence of interest groups.

Hence, the paper will be structured as follows: after this introduction (Section 1) an historical overview of the use of financial caps in maritime law will be provided (Section 2). Next, the caps in the international conventions on oil pollution damage will be described on the basis of an analysis of their legal history and the subsequent evolution of the conventions (Section 3). The limitation of liability for oil pollution damage has been criticized in legal and economic literature; a brief summary of this critique in the literature is provided (Section 4). Next a simple economic analysis of financial caps for oil pollution damage is provided on the basis of the economic analysis of accident law (Section 5). Subsequently, the economic analysis is linked with the historical analysis by asking the question whether the financial caps should be considered as a historical mistake (Section 6). A few concluding remarks follow (Section 7).

\section{History of financial caps in maritime law}

\subsection{Overview}

The general principle in tort law is restitutio in integrum, meaning that the victim shall receive full compensation, if the conditions for tort liability are met. However, there are exceptions to this principle, where the liability of the tortfeasor is capped to a certain amount. In maritime law, this is known as the limitation of liability of the shipowner (and its representatives).

The precise origin of limitation of liability in maritime law is not entirely clear, but it has a long history in maritime tradition [2], and it has now been widely employed in various areas related to shipping activities. However, today the concept of the limitation of liability in maritime law is also subject to criticism [1]. Internationally, there have been conventions on the limitation of liability of the shipowner and its representatives, mainly the International Convention for the Unification of Certain Rules Relating to the Limitation of Liability of Owners of Sea-going Vessels (Limitation Convention 1924), International Convention relating to the Limitation of the Liability of Owners of Seagoing Ships 1957 (Limitation Convention 1957), Convention on Limitation of Liability for Maritime Claims 1976 (LLMC 1976) and its 1996 Protocol (LLMC 1996). In addition, in various specific areas of maritime activities, there are conventions which provide for the limitation right as well. For example, for the carriage of goods by sea, the carriage of passengers by sea, and for the transportation of hazardous and noxious substance by sea, there are different conventions allowing shipowners to cap their liability. ${ }^{1}$ In the area of oil shipping, there is the International Convention on Civil Liability for Oil Pollution Damage of 1969 (the CLC), which grants the shipowner the right to limit his liability as in other maritime shipping activities.

The limitation of liability is not a mechanism peculiar to maritime law. Carriers in other forms of transportation, e.g. transport by road and air, are also entitled to such a limitation right [3]. ${ }^{2}$ More recently, when nuclear energy was discovered, conventions were adopted which equally grant the right of limitation to the operator of a nuclear power plant. ${ }^{3}$ Hence, to cap the liability of the tortfeasor to a certain amount is far from being unique to maritime law, but it is particularly important in the context of maritime law due to its long tradition and widespread influence in various areas of maritime activities. The limitation of liability is considered the backbone of maritime law and many other institutions in maritime law developed on the basis of the limitation system [4]. ${ }^{4}$

\footnotetext{
${ }^{1}$ These conventions include, inter alia, the International Convention for the Unification of Certain Rules of Law relating to Bills of Lading of 1924 and its 1968 Protocol, United Nations Convention on the Carriage of Goods by Sea 1978, which are the conventions for transport of goods by sea; the Convention relating to the Carriage of Passengers and their Luggage, which is the convention for the carriage of passengers by sea; the International Convention on Liability and Compensation for Damage in Connection with the Carriage of Hazardous and Noxious Substances by Sea 1996, which is the convention for transportation of hazardous and noxious substances by sea.

${ }^{2}$ E.g. in the Convention for the Unification of Certain Rules relating to International Transportation by Air, known as the Warsaw Convention 1929 , the air carrier's liability for the death or injury of the passenger is limited to $\$ 75,000$ per passenger.

${ }^{3}$ Paris Convention on Third Party Liability in the Field of Nuclear Energy, 1960.

${ }^{4}$ The Protection \& Indemnity Clubs owe their origin to the first UK legislation which exposed ship owners to potential liabilities larger than the value of the ship plus pending freight. It provided a limitation fund based on a sterling multiple of the ship's tonnage and made it impossible to provide for liability coverage as part of the normal hull insurance. So it has been said that the present system of the ship owner's liability insurance is therefore literally built on the concept of limitation.
} 
Table 1

Caps in oil pollution (in USD) ${ }^{\mathrm{a}}$

\begin{tabular}{|c|c|c|c|c|}
\hline Ship tonnage & 1969 CLC & 1992 CLC & 2000 Amendment & \\
\hline$\leqslant 5000$ ton & 203/ton & 4.5 million & 7 million & \\
\hline$>5000$ ton & $203 /$ ton & 4.5 million $+636 /$ ton & 7 million $+963 /$ ton & \\
\hline \multirow[t]{2}{*}{ Overall limit } & 21 million & 90 million & 136 million & \\
\hline & 1971 Fund & 1992 Fund & 2000 Amendment & 2003 Fund \\
\hline Maximum per incident & 91 million & 204 million & 307 million & 1134 million \\
\hline
\end{tabular}

"The original "unit of account" provided in the Conventions is "the Special Drawing Right as defined by the International Monetary Fund" (referred to

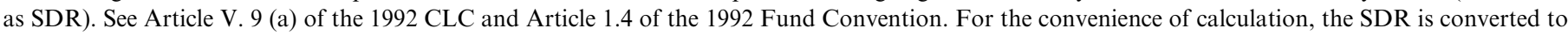

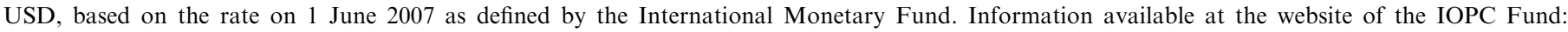
www.iopcfund.org/SDR.htm, last accessed on 31 August 2007.

\subsection{Development of financial caps in maritime law}

As mentioned before, the origin of the limitation of liability as a concept is not so clear, and there are different opinions concerning this issue. Some scholars believed that the Amalphitan Table of Italy in the 11th century is "the earliest extant evidence of the shipowner's right to limit his liability" [5-7]. Some other scholars believed that the right of a shipowner to limit his liability dated back to the 17 th century, as exemplified by the provisions on limitation in the Statutes of Hamburg 1603, the Hanseatic Ordinances 1614 and 1644, and in the Maritime Code of Sweden 1667 [3]. Most importantly, the Maritime Ordinance of Louis XIV 1681 codified maritime law in France and was used as a model in the Netherlands, Venice, Spain and Prussia (Tables 1 and 2).

The international maritime world decided to unify the rules on limitation of liability at the beginning of the 20th century. This led to the conclusion of the Limitation Convention 1924. This convention entered into force in 1931, but it had little practical value because major shipping countries did not adopt it. ${ }^{6}$ It was hence abrogated by the Limitation Convention 1957.

Under the Limitation Convention $1957,{ }^{7}$ a broad class of parties can enjoy the right of limitation, which include the charterers, managers and operators; the limitation amounts were increased.

The LLMC $1976^{8}$ has replaced the Limitation Convention 1957 and has considerably increased the limitation amounts and expanded the individuals who are entitled to limit their liability. Under the LLMC 1976, a distinction

\footnotetext{
${ }^{5}$ According to Donovan [7], the Amalphitan Table (also known as Tables of Amalfi) was a commercial code compiled for the 'free and trading Republic of Amalphia' (Italy).

${ }^{6}$ There were 15 countries that ratified or acceded to the 1924 Convention, but six of them have denounced it. Data from the website of CMI: www.comitemaritime.org.

${ }^{7}$ International Convention relating to the Limitation of the Liability of Owners of Sea-going Ships, adopted 10 October 1957, entered into force 1968.

${ }^{8}$ Convention on Limitation of Liability for Maritime Claims 1976, adopted 19 November 1976, entered into force 1 December 1986.
}

Table 2

Compensation (in USD) $[51]^{\mathrm{a}}$

\begin{tabular}{llll}
\hline Ship & Year & $\begin{array}{l}\text { Available } \\
\text { compensation } \\
\text { (million) }\end{array}$ & $\begin{array}{l}\text { Damage } \\
\text { caused } \\
\text { (million) }\end{array}$ \\
\hline Tanio & 1980 & 43.9 & 62.6 \\
Haven & 1991 & 62.5 & 71.6 \\
Aegean Sea & 1992 & 63.5 & 115 \\
Braer & 1993 & 86.9 & 89.2 \\
Nakhodka & 1997 & 196.3 & 215.6 \\
Erika & 1999 & 200 & 450 \\
Prestige & 2002 & 200 & 877 \\
\hline
\end{tabular}

${ }^{\mathrm{a}}$ We have taken the estimates of damage caused from the thesis of Julien Hay (see Ref. [51]). The amounts for the Erika and Prestige incidents are estimates based on the Annual Report 2005 of the IOPC Fund. The amounts have for reasons of simplicity and comparability all been transformed to US Dollars. The exchange rate used here is also from the Annual Report 2005 of the IOPC Fund.

was made between claims for loss of life or personal injury and claims for property damage. The LLMC $1996^{9}$ further increased the amounts of limitation and introduced a tacit acceptance procedure for updating the limitation amounts.

\subsection{Justifications from a historical perspective}

From the enactment of the early laws on the limitation of liability, some observations can be made concerning the motives for introducing financial caps in maritime law.

First, a limitation of liability for the shipowner was originally needed to encourage the development of shipping activities which were considered risky at the time. Second, the promotion of the national merchant fleet under the competitive pressure led to the decision of various countries to introduce a financial cap on the liability of shipowner into their legislation [8,9].

However, with the change of the commercial structure and the modern technology, these reasons advanced in the 17 th century were not valid any more. A more recent justification for the limitation of liability concerned a fair

\footnotetext{
${ }^{9}$ Protocol of 1996, adopted 3 May 1996, entered into force 13 May 2004.
} 
risk distribution [4]. There are risks inevitably attached to a maritime adventure (even with modern technology) and it was considered equitable to make all those who benefit from the activity bear the risks in order to achieve an equitable risk distribution among them.

Another justification developed in modern theory was the protection of the carrier, and of those who benefit from the shipping activities [8]. It was argued that if the carrier had to bear all the risks and related costs without a limitation, he might be either driven out of business (whereby the choice of vessels available to cargo owners are reduced), or would be forced to pay a high premium for insuring his potential liability (which would result in the increase of the freight he charged to the cargo owner).

A third justification for financial caps in the context of modern trade is that a statutory limitation of liability is necessary to meet the needs of liability insurance. ${ }^{10}$ It was often argued that the capacity of the insurance market was not infinite. Unlimited liability was considered uninsurable, or at least the insurance costs would be unreasonably high. Moreover, the insurance costs already constituted a large part of the operational costs. To expose the shipowner to unlimited liability would lead to a high premium which would constitute a too heavy burden for the shipping industry, so it was held [4].

\section{Caps in international conventions on oil pollution damage}

\subsection{Overview of the limitation of liability for oil pollution damage}

The international regime on oil pollution damage compensation was originally established through two conventions, the International Convention on Civil Liability for Oil Pollution Damage 1969 (the CLC 1969) and the International Convention on the Establishment of an International Fund for Compensation for Oil Pollution Damage 1971 (the Fund Convention 1971). The CLC 1969 imposed a strict liability of the shipowner capped to certain amount with the requirement of compulsory insurance. The Fund Convention 1971 provided a second tier of compensation contributed by the oil industry. These two conventions were amended in 1984, but due to the failure of the US to ratify these amendments, they did not come into force. Hence, most of the changes made in 1984 were taken over in the 1992 Protocols whereby the caps in the CLC and the compensation from the Fund were both substantially increased. As a reaction to the oil spills of Erika (1999), the 1992 Conventions were amended in October 2000, whereby the financial caps were increased by $50 \%$, with effect from November 2003; later, in reaction to the Prestige incident (2002), a Supplementary Fund contributed by the oil industry was established in 2003 to provide a third tier of compensation, which entered into

\footnotetext{
${ }^{10}$ The insurance factor was emphasized during the drafting for the CLC 1969, LLMC 1976 and HNS Convention 1996.
}

force on 3 March 2005. As a result, the total amount available for the oil pollution compensation (in the countries that have ratified the 2003 Protocol) has reached 750 million SDR (around US\$1134 million) [10]. ${ }^{11}$

As a reaction to the Supplementary Fund, the International Group of P\&I Clubs offered to increase on a voluntary basis the indemnification amount of small tankers it eventually pays to the Fund. This is known as Small Tanker Oil Pollution Indemnification Agreement (STOPIA), which came into effect on 3 March 2005, the same date as the entry into force of the Supplementary Fund. The effect of the STOPIA is that the maximum amount of compensation payable by shipowners (ultimately the P\&I Clubs) whose ships are of 29,548 gross tonnage or less would be 20 million SDR. ${ }^{12}$ The original STOPIA applies only to the Supplementary Fund member states. In 2006, through the STOPIA 2006, it was extended to the 1992 Fund member states as well. In addition, the International Group of P\&I Clubs made another offer called TOPIA (Tanker Oil Pollution Indemnification Agreement) 2006 to indemnify the Supplementary Fund for $50 \%$ of the compensation it has to pay for an incident. ${ }^{13}$ However, these most recent changes of STOPIA 2006 and TOPIA 2006 do not concern the compensation for oil pollution victims (hence the financial caps) as such, but merely how the costs of oil spills are re-allocated between the shipping and the oil industries. Therefore, these recent developments are less relevant for the central issue of this paper, being the financial caps.

\subsection{Introduction of financial caps in the oil pollution compensation regime}

At the 1969 diplomatic conference which led to the conclusion of the CLC 1969, most of the debate centered on who should bear the liability for the compensation of oil pollution damage, and whether it should be a strict liability or liability based on negligence. However, after rounds of discussion, no agreement could be reached concerning these issues. The Belgian delegation submitted a proposal on an international compensation fund, an idea which was originally developed by French legal experts [11]. This scheme immediately attracted the attention of many delegations, and they mostly changed their attitudes towards a compromise solution. In this situation, the UK delegation proposed a compromise package deal. It proposed to impose strict liability on the shipowner, while capped to the highest amount that was insurable. According to the UK delegate, this would be 1900 francs per tonne with a ceiling of 210 million francs [12,13] Other delegations proposed figures varying from 1000 to 3000

\footnotetext{
${ }^{11} \mathrm{SDR}$ stands for special drawing rights, and it is defined by the International Monetary Fund. The conversion rate used here is the rate on 1 June 2007. Information available at the website of the IOPC Fund: http://www.iopcfund.org/SDR.htm, last accessed on 31 August 2007.

${ }^{12}$ See Articles III and IV of the STOPIA.

${ }^{13}$ See Article IV of the TOPIA.
} 
francs per tonne. However, envisaging the establishment of a compensation fund financed by the oil industry, the delegations accepted the UK compromise proposal, with a slight change from 1900 to 2000 francs, simply for the convenience of calculation [13]. Hence, the CLC 1969 provided in Article $\mathrm{V}$ that the owner may limit his liability "in respect of any one incident to an aggregate amount of 2000 francs (133 SDR) for each tonne of the ship's tonnage. However, this aggregate amount shall in any event not exceed 210 million francs (14 million SDR)".

It may seem striking that at the 1969 conference, there was little debate on whether to accept the financial caps as a principle, and it was mainly justified in order to obtain insurance and as a compromise to counterbalance the harsh effect of strict liability. It was probably due to the long history of the limitation system in maritime law and the time pressure to come with an international regime that the limitation as a principle was not debated as such. There was only some debate concerning the specific figures of the financial caps. The delegations agreed on some general principles, such as that the amount should provide adequate compensation to the victims, which corresponds with the magnitude of the damage [14,15]; this amount should be the maximum amount that is insurable, given the fact that the insurance capacity is not unlimited $[13,14]$; the caps should also take into account the costs for cleaning up the oil pollution [14].

However, these general principles did not provide a justification for the particular amounts proposed, and interestingly, the final adjustment of the figure was simply to make the calculation easier. The finally adopted figure doubled the existing financial caps under the Limitation Convention 1957, but it was still considered acceptable by most of the delegations since it would not be too high to stop the major maritime countries from ratifying the convention. The limitation of liability with such an amount was introduced together with the strict liability on the shipowner as a compromise solution [13].

\subsection{4 protocols}

\subsubsection{Increase of the limitation amount}

The CLC 1969 came into effect in 1975 and the Fund Convention in 1978. Shortly after, the financial caps introduced were challenged by some major oil spill incidents, including the Amoco Cadiz in 1978, which caused damage higher than the limited amount provided in the CLC 1969. This triggered the convening of the 1984 diplomatic conference to revise the international oil pollution compensation regime.

Most delegations at the 1984 conference agreed that the balance established under the CLC/Fund regime should be maintained [16-18]. Thus, according to them, the increase of financial caps under the CLC should be accompanied with the increase of compensation under the Fund Convention. As a result, the debate on the increase of the compensation focused on the increase of both the CLC and the Fund simultaneously.

Despite some divergence concerning the degree of increase of the financial caps $[16-18],{ }^{14}$ the delegations generally agreed that the existing compensation amounts needed to be revised. Their main arguments for increasing the financial caps included inflation, the increased capacity of the insurance market and the increased clean-up costs $[16,17,19,20]$.

Two particular issues were raised relating to the limitation of the liability system. One was related to the calculation of the limitation amounts. More precisely it concerned the question whether the basis of the limit should remain on the tonnage of the ship. The OCIMF ${ }^{15}$ produced some graphs to show that there was no clear relationship between the size of ships and the cost of oil spills, and it therefore proposed to abandon the tonnagerelated system and adopt fixed limitation amounts for all ships. ${ }^{16}$ However, most government delegations attached great importance to the tonnage related system and they considered that the calculation of the limitation of liability of the shipowner should continue to be based on the tonnage of the ship [16-18]. ${ }^{17,18}$ Hence, despite some differing opinion from observers, the link between the limitation and tonnage was nevertheless maintained.

Another issue concerned the financial caps for small ships. The CLC 1969 did not prescribe any minimum amount to be paid in case of incidents involving small tankers. However, the small tankers may nevertheless cause large scale damage. This resulted in the situation that victims receive disproportionately small amount of compensation compared to the amount of damage sustained [21,22]. It was pointed out by the International Group of P\&I Clubs and some other delegations that where there is a minimum for small ships, the chances of an intervention from the Fund for minor cases would be

\footnotetext{
${ }^{14}$ Some delegations believed a moderate increase would be sufficient, some believed in a substantial increase to cover even the catastrophic cases as well.

${ }^{15}$ OCIMF stands for Oil Companies International Marine Forum. It was founded on 8 April 1970 in London and was initially the response from the oil industry to the Torrey Canyon. It includes oil companies shipping over $85 \%$ of the world's crude and fuel oil. It has been granted a consultative status at IMO since 1971.

${ }^{16}$ See also the OCIMF Statement, July 1982, LEG/CONF.6/INF.3, p. 376-378. Nevertheless, this document was criticized during the Legal Committee meeting in 1982 for the way in which the statistics had been selected. In addition, the International Group of P\&I Clubs (LEG/ CONF.6/14), in its table on the distribution of incidents by ship size, concluded that there seemed to be no direct correlation between ship size and the cost of spill, although spills from small ships were less frequent than from large ships, and the average costs per incident increased with ship size. However, the International Group of P\&I Clubs remained in favor of a tonnage related system on the basis of other considerations.

${ }^{17}$ Japan, China, Canada, Italy and Morocco expressed their support for the tonnage related system.

${ }^{18}$ Democratic Republic of Germany, Sweden, Bahamas and some organizations with observer status were also in favor of the tonnage related system.
} 
reduced. ${ }^{19}$ If the Fund were regularly called upon, its usefulness would be doubtful; thus most delegations considered that there should be a minimum liability for small tankers $[16-18] .{ }^{20}$ On the other hand, some delegations also pointed out that such limitation for small ships should not be too high in order not to put an undue burden on small ships [18].

The amounts proposed by different delegations were largely diverse, the financial caps for shipowners under the CLC varied from $\$ 30$ to 100 million. As for small ships, the tonnage varied between 5000 and 30,000 ton, and its minimum threshold varied from $\$ 3$ to 15 million. ${ }^{21}$ After consultation with many delegations, The Chairman proposed a package proposal. Under the CLC, for small ships of less than 5000 GRT, the maximum liability should be 3 million SDR; above that, 420 SDR per tonne, capped at 59.7 million SDR (140,000 GRT). Under the Fund, the basic coverage (including payment from the shipowner) should be 135 million SDR; the expanded coverage (including payment from the shipowner) should be 200 million SDR. The expanded coverage is when the contributing oil from three states equals to 600 million tonnes [23,24]. Most delegations, although not completely satisfied with the proposal, were still willing to accept it in order to reach at least some positive results [24]. ${ }^{22}$

Thus the amounts as proposed by the Chairman were agreed upon [25].

\subsubsection{Loss of limitation right}

Under Article V. 2 of the CLC 1969, the shipowner would lose the right to limit his liability if "the incident occurred as a result of the actual fault or privity of the owner". ${ }^{23}$ As the shipowner was often guilty of actual fault or with privity, it could lead to some problems in practice. The determination of the existence of fault or privity often delayed the compensation process, not only because the settlement was postponed, due to the difficulty in determining whether the shipowner could take advantage of the limitation, but also the Fund could not settle the claims before the limitation was decided [26]. ${ }^{24}$ Moreover, different national courts often gave different interpreta-

\footnotetext{
${ }^{19}$ In the document submitted by the P\&I Clubs (INF.3), according to its data in Table 7, among the 14 spills of ships of less than 1000 ton that Fund has intervened, if there were a minimum threshold, the Fund would not have compensated.

${ }^{20}$ For instance, the US, Canada, France, The Netherlands, UK, German Democratic Republic, Finland, Greece, USSR, Norway, Sweden, Denmark.

${ }^{21}$ Summarized by the chairman, see OR 1984, SR.6, 382. There were other proposals such as the proposal from UK, Federal Republic of Germany, Democratic Republic of Germany, Japan, USSR, see OR 1984, SR.6, 375-379.

${ }^{22}$ See the view expressed by delegations such as Chile, Malaysia, UK, US, Denmark, France, Netherlands, Sweden and Canada.

${ }^{23}$ Art.V.2 of the CLC 1969.

${ }^{24}$ According to the P\&I Clubs, the criterion of 'fault or privity' which determines whether the ship owner is entitled to limit his liability was one of the most glaring defects of the CLC.
}

tions of the concept of "fault or privity" which led to disparities in the compensation for oil pollution damage in the contracting states [27].

At the 1984 conference, most delegations were in favor of changing such a provision on the conditions to lose the limitation right and adopt the same wording as in the 1976 LLMC, which provided that "The owner shall not be entitled to limit his liability under this Convention if it is proved that the pollution damage resulted from his personal act or omission, committed with the intent to cause such damage, or recklessly and with knowledge that such damage would probably result".

The new criterion on the loss of limitation right was regarded as involving a considerable increase of the liability limits since it made the right to limit almost unbreakable [27,28]. But these delegations believed unbreakability was important for the limitation of liability [29]. As a result, the same wording as adopted in the LLMC 1976 was finally approved [30]. ${ }^{25}$

Such a provision implies that the burden of proving that the conditions for breaking the limit are fulfilled was laid on the claimant. ${ }^{26}$ Some research has come to the conclusion that the 1984 provision on breaking the right of limitation is stricter and much harder to circumvent than the 1969 provision. Hence, it provides better protection for the shipowners than the CLC 1969 [27]. There was also the view that such a test in the 1984 Protocol was very close to the insurance law concept of "willful misconduct" under the marine insurance policy. Consequently, it was concluded that when the owner loses his right of limitation, he also loses his liability insurance cover. The implication of this for practice might be that claimants would be discouraged from challenging the shipowner's right of limitation of liability [27-29]. If they were not confronted with a financial cap on liability, they might then be confronted with a defendant without insurance cover.

\subsection{Protocols}

The entry into force conditions in the 1984 Protocols were laid down in such a way that the Protocols could not come into effect until the US ratified them. However, when the US was hit by the Exxon Valdez in 1989, it decided to adopt its own national regime (the Oil Pollution Act 1990) which closed the door for the US to ratify the international conventions. Still, the changes made in the 1984 Protocols were needed, as demonstrated by the oil spills such as Exxon Valdez. Moreover, there was a growing sentiment, especially among the European member states to the Conventions, that something had to be done to bring the substance of those instruments into force in order to keep the international system up to date and to avoid the threat of further regional schemes like the one adopted by the US.

\footnotetext{
${ }^{25}$ Sweden, Netherlands, Norway.

${ }^{26}$ The same applied to the LLMC 1976, and the same point was made at the 1984 Conference, see OR 1984, LEG/CONF.6/SR.13, 456.
} 
France played an important role in the revision process because it had suffered the greatest exposure to the risks of oil spills. Thus another diplomatic conference was convened in 1992 to take up the changes made in 1984 while eliminating the need of US participation.

The CLC 1992 has increased the financial limits to the amounts which were originally agreed in the 1984 Protocols.

\subsection{Amendments and 2003 Supplementary Fund Protocol}

The compensation amounts under the 1992 Conventions (the CLC 1992 together with the increased compensation under the Fund Convention 1992) were considered at the time sufficient to cover most of the oil spill incidents. However, the Erika incident in 1999 and Prestige in 2002 again showed that such a limited amount was far from sufficient. The European Commission published several packages of legislation proposals known as the Erika I, [30] Erika II [31] and Erika III proposals. The Commission in the Erika I proposals condemned the financial caps as provided in the international conventions as being insufficient; the victims of serious oil spills would remain inadequately compensated. In the Erika II proposals, the Commission even proposed to set up a regional fund for Europe. ${ }^{27}$ Threatened by the EU regional actions, the IMO quickly increased the financial caps (together with the compensation provided from the Fund) by $50.37 \%$ in 2000 through the adoption of two Amendments. ${ }^{28}$ Later in 2003, a Supplementary Fund Protocol was adopted to provide a third tier of compensation. The amounts in the 2000 Amendments, in comparison with those under the CLC 1992, are as follows:

- For a ship not exceeding 5000 gross tonnage: liability is limited to 4.5 million SDR (US\$ 7 million) (compared with 3 million SDR under the CLC 1992);

- for a ship of 5000 to 140,000 gross tonnage: liability is limited to 4.5 million SDR (US\$ 7 million) plus 631 SDR (US\$ 963) for each additional gross tonne over 5000 (compared with 3 million SDR plus 420 SDR for each additional gross tonne under the CLC 1992);

- for a ship over 140,000 gross tonnage: liability is limited to 89.8 million SDR (US\$ 136 million) (compared with 59.7 million SDR under the CLC 1992).

The historical evolution of the caps and the available amount of compensation can be summarized as follows:

\footnotetext{
${ }^{27}$ See in this respect the amended proposal for a regulation of the European Parliament and of the Council on the Establishment of a Fund for the Compensation of Oil Pollution Damage in European Waters and Related Measures, Official Journal C227 E/487, 24 September 2002.

${ }^{28}$ Two Resolutions concerning the Amendments were adopted. These are Resolution: Adoption of Amendments of the Limitation Amounts in the Protocol of 1992 to Amend the International Convention on Civil Liability for Pollution Damage, 1969, and Resolution: Adoption of Amendments of the Limits of Compensation in the Protocol of 1992 to Amend the International Convention on the Establishment of an International Fund for Compensation for Oil Pollution Damage, 1971.
}

\subsection{Evaluation}

The principle to limit the liability of the shipowner was easily accepted at the 1969 conference, even without discussing the legitimacy of shifting the effect of the limitation to innocent third party victims. Compared with the prior situation where the liability of the shipowner was based on general tort principles or fault, the strict liability imposed on the tanker owner by the convention was rather harsh. The limitation of liability was thus welcomed because it could to a certain extent alleviate the severe impact on the shipowner through the shift to strict liability. Therefore, the limitation of liability is considered a mechanism of cost sharing between all those involved in and benefiting from the maritime adventure, rather than imposing all the losses on one single party [4]. ${ }^{29}$

Another justification for the limitation employed by the delegations at the 1969 conference is to make the shipowner's liability insurable as it introduces an element of predictability [4]. However, this argument is also doubtful as the liability can be unlimited while the amount of insurance can be restricted to a certain amount.

The limitation adopted in the CLC 1969 had almost doubled the then existing limit under the Limitation Convention 1957, but the limitation amount has been substantially increased since then. It is interesting to notice that victim compensation was set out as the goal of the international convention in 1969 , but in order to strike the balance so that it can be widely accepted by the major maritime nations, a paradoxical limitation of liability was introduced. However, even more paradoxically, this amount was again and again criticized for being insufficient and thus needed to be updated. Thus, one may wonder what the rationale is of limiting the liability.

\section{Critiques of the limitation of liability}

Not only the financial caps in the marine oil pollution compensation regime, but caps in maritime law as such have often been criticized by both lawyers and economists.

A first critique is that financial caps in maritime law in fact constitute a subsidy to the shipping industry at the cost of other interests (more particular of the injured party). It has been argued that in the early days of shipping the caps were needed as a stimulant for investment in shipping due to its highly risky nature, but this historical justification is no longer valid, and the widespread use of insurance, particularly third party liability insurance, could considerably reduce such risks [1]. Financial caps allow the industry to pay only part of the damage it has caused. Ultimately it will be society at large that bears the cost of damage caused by shipping [9]. However, no country is willing to take away the subsidy from their industry because they are

\footnotetext{
${ }^{29}$ The modern theory on the limitation of liability justifies the limitation as a means to achieve 'an equitable distribution of the risks inevitably attached to a maritime adventure'. See Seward [4].
} 
afraid that they would expose their shipping industry to competitive disadvantages [32,33]. This might explain the long survival of financial caps notwithstanding these criticisms.

A second critique concerns the relationship between the financial caps and liability insurance. It is often argued that the statutory limitation of liability is necessary to obtain insurance. One could equally presume a situation where the limitation of liability and insurance were separated, with the consequence that the liability of the shipowner remained unlimited, but the insurance provided cover only to a certain amount $[1,9]$. Wetterstein argued that the insurance industry's capacity should not constitute an obstacle to unlimited liability because the special structure of marine liability insurance (through P\&I Clubs) and reinsurance (through pooling agreement between the Clubs), facilitate a very substantial (and growing) capacity [9]. Indeed, the most recent change took place in 2006 when the small tankers insured by the P\&I Clubs agreed voluntarily to increase their financial caps. ${ }^{30}$ This change once more showed the potential capacity of the insurance market.

Another often quoted argument for maintaining the financial limits is that the introduction of unlimited liability would increase the operating costs for the shipowners [34]. However, according to empirical studies, this would only lead to a marginal increase in overall operating costs.

On the other hand, there is a relative advantage of unlimited liability (while liability insurance is capped to a certain amount), being that it provides incentives for prevention. In such a situation, there will be liability exceeding the insurance ceiling, which will then be born by the activity causing such damage, and it will in turn provide incentives for prevention [9].

\section{Economic analysis of financial caps}

The previous section made clear that both lawyers and economists have already been critical of financial caps especially in the domain of oil pollution damage. We will now address financial caps in maritime law generally and more particularly with respect to oil pollution damage using traditional economic analysis of law, more particularly the Coase theorem and the economics of accident law. First the consequences of a financial cap on liability in the contract situation will be analyzed (Section 5.1), next attention will be given to the situation where the victim is (like in the oil pollution case) a third party who does not stand in a contractual relationship with the injurer (Section 5.2). Then the question will be asked what the potential effects are of a financial cap on the liability (Section 5.3). To be clear: within the context of this paper we only address one aspect of the international oil pollution compensation regime, being the financial cap on liability; other aspects of this regime, such as the exclusive

\footnotetext{
${ }^{30}$ See on this so-called STOPIA 2006 and TOPIA 2006.
}

channelling of the liability to the tanker owner have been critically analyzed elsewhere $[35,36]$.

\subsection{The contract situation}

The starting point for any economic analysis, including the analysis of the compensation for victims of oil pollution is undoubtedly the Coase theorem [37]. One can argue that the Coase theorem does have a relevance in the sense that there is a contractual relationship between the tanker owner who agrees to transport cargo with his tanker and on the other hand the party representing the cargo interests. In such a contractual bargaining setting parties could in principle ex ante agree on the optimal amount of care to be performed by the tanker owner and on the damages, which could be related to the specific preferences of both parties and to e.g. their ability to seek insurance coverage. In that case the agreement concerning the distribution of risk might also be reflected in the contract price that has to be paid for shipping the oil (the freight) [38].

A result of this reasoning is that it would in the context of liability for oil pollution damage in theory make no difference whether liability is allocated to either the tanker owner or to the cargo interests. As long as free negotiations (in a low transaction cost setting) are possible, shifting the liability to the tanker owner would simply mean that the price charged for transport would be increased. In the alternative it would be the cargo owner (on the assumption that that would be the governing rule) that would bear the liability. In any event the cargo interests will pass on the costs of liability for oil pollution damage to the end user of the cargo, being those who have a demand for oil related products.

The Coase theorem of course only applies in the situation where passing on of costs of a tanker owner and the cargo interests is possible and may hence have its importance for the question whether liability should be allocated to one of these parties. On the assumption that the conditions of the Coase theorem are met one could argue that this should in principle not make a difference. It may only be different if costless passing on of increased liabilities were not possible.

The same conclusion could also be reached with respect to the issue discussed in this paper, being a financial cap on liability. Such a so-called financial cap is from a policy perspective not too problematic as long as this is (implicitly) agreed between a potential injurer (tanker owner) and a victim within a contractual setting. In the contractual setting well informed parties may agree to cap liability; in that particular case there is as such no specific reason for a legislative intervention, to prohibit a cap.

From this it follows that a distinction has to be made between the situation where the victim stands in a contractual relationship with the injurer and the one where the victim is a third party. 
As we have just indicated, discussing the Coase theorem, financial caps on liability can be efficient in the contractual setting. In that case they could simply signal the division of risk bearing between the cargo owner and the tanker owner. Traditionally in maritime law there were always financial caps on the liability of the shipowner as maritime transporter. ${ }^{31}$ A limited liability will, of course, be reflected in the transport price. In this particular contractual setting, where informed parties agree to cap liability, this should not cause major worries from a policy perspective.

This therefore corresponds with the traditional justification advanced in maritime law in favor of the limitation of liability (see Section 2.3) whereby the cap is considered as striking a balance between the interest of the cargo owners and the shipping industry.

The cap on liability in the contract setting, moreover, has the advantage that the potential victim could, depending upon his preferences and attitude to risk, purchase individualized insurance coverage. A generalized unlimited liability of the shipowner could lead to a general increase of shipping prices also for those potential victims who do not want this additional protection. It is a classic argument in the economic analysis of law against strict liability in these situations where increased liabilities can be passed on: prices may be increased for all whereas only some (high risk) individuals may benefit from this increased protection. An efficiency loss and a negative redistribution may be the result [39-43].

\subsection{Third party losses}

The situation is of course different when, as in the case of oil pollution damage, the victim is not a party standing in a contractual relationship with the injurer, but a third party. In that case transaction costs are prohibitive and hence Coasean bargaining may not provide a solution.

Given the fact that many victims of oil pollution damage (e.g. coastal states) may not stand in a contractual relationship with the tanker owner, a legislative intervention is necessary to remedy the externality resulting from oil pollution damage. A legal rule should thus be put in place to give the tanker owner appropriate incentives to follow an optimal care level. The economic literature on accident law has largely demonstrated that liability rules may be put in place to serve this goal $[44,45]$. The outcome of this literature can well be applied to the case of oil pollution damage as well.

Usually a distinction is made in the literature between the so-called unilateral accident case, being the one where only one party (referred to as the injurer) can influence the accident risk and the bilateral accident situation (where the victim can influence the accident risk as well). This distinction also has its importance for the analysis of financial caps.

\footnotetext{
${ }^{31}$ See Section 2
}

\subsubsection{Unilateral accident situation}

The literature holds that in a so called unilateral accident case, being one where only the injurer can influence the accident risk, both negligence and strict liability lead to efficient care levels, but only strict liability leads to an efficient activity level of the injurer as well [46,47]. Only under strict liability would the potential injurer have an incentive to adopt an optimal activity level. This full internalization is obviously only possible if the injurer is effectively exposed to the full costs of the activity he engages in and is therefore in principle held to provide full compensation to a victim. An obvious disadvantage of a system of financial caps is that this will seriously impair the victim's rights to full compensation. If the cap is indeed set at a much lower amount than the expected damage, this would not only violate the victim's right on compensation, but the above mentioned full internalization of the externality would not take place either. From an economic point of view, a limitation of compensation therefore poses a serious problem since there will be no internalization of the risky activity. Indeed, if one believes that the exposure to liability has a deterrent effect, a limitation of the amount of compensation due to victims poses another problem. There is a direct relationship between the magnitude of the accident risk and the amount to be spent on optimal care by the potential polluter. If the liability therefore is limited to a certain amount, the potential injurer will consider the accident as one with a magnitude capped at the limited amount. Hence, he will not spend the care necessary to reduce the total accident costs. Obviously, the amount of care spent by the potential injurer will be lower and a problem of underdeterrence will arise. The amount of optimal care, reflected in the optimal standard, being the care necessary to reduce the total accident costs efficiently, will be higher than the amount the potential injurer will spend to avoid an accident equal to the statutory limited amount.

The same problem also arises under strict liability from the moment that the amount of the damage is higher than the injurer's wealth. In that case insolvency has the same negative effects on deterrence as a financial cap and a negligence rule would even be preferred. However, the solution for the potential insolvency problem (which can also arise under oil pollution) is not to shift to the (inefficient) negligence rule, but rather to impose a duty to seek financial coverage such as e.g. compulsory insurance [36]. ${ }^{32}$

\subsubsection{Bilateral accidents}

The picture, however, changes somewhat when account is taken of the victim's influence on the accident risk as well. This is usually referred to as the bilateral accident situation. In that case it is held that no liability rule is

\footnotetext{
${ }^{32}$ Therefore we have argued elsewhere (see [36]) that the introduction of compulsory insurance is a necessary component of a strict liability regime for oil pollution damage in order to prevent underdeterrence.
} 
optimal. ${ }^{33}$ It is, thus, important to stress that from the economic literature it follows that whenever the victim can have its influence on the care level as well (so-called bilateral accidents) a liability rule should be chosen that provides incentives to the victim for taking optimal care as well. This may either be a negligence rule or a defence which has to be added to the strict liability rule (comparative or contributory negligence) [48]. ${ }^{34}$

This difference between the unilateral and the bilateral accident may also have its importance for an economic evaluation of financial caps. In the unilateral accident situation it was argued that a full exposure of the injurer to the costs of his activity is necessary in order to fully internalize the costs caused by oil pollution damage.

The conclusion may, however, be different in case of bilateral accidents, where the victim's behavior may also affect the accident risk. The standard argument against providing full compensation to victims in case of bilateral accidents is that victims can take precautionary measures which are not always observable by judges and which can therefore not be fully accounted for in contributory or comparative negligence defences $[41,49,50]$. A limit on the compensation in case of bilateral accidents may therefore be useful in cases where victims should be given additional incentives to reduce the accident risk. Whether caps are efficient in specific bilateral accident cases will depend on the circumstances. The question arises-inter aliawhether exposing the victim to risk is indeed necessary to provide these additional incentives or whether the victim's incentives can be optimally controlled via the contributory negligence defence. Also the amount of the cap remains important. If the cap were set too low this would give incentives to the victim but it could equally lead to serious underdeterrence of the injurer.

\subsection{Effects}

The previous subsection showed that there are relatively few reasons to introduce financial caps in case of liability towards third parties. The question now arises what the potential effects may be if such a cap is nevertheless introduced in liability.

\subsubsection{Underdeterrence}

In this respect we can be brief: the economic literature shows that a strict liability rule is efficient only if the potential tortfeasor is fully exposed to the potential damage which may result from his activity. A financial limit on the (strict) liability of the tanker owner will have the same effect as the insolvency of the tanker owner:

\footnotetext{
${ }^{33}$ For the simple reason that strict liability with a contributory negligence defence will give optimal incentives for care and activity level to the injurer, but not to the victim (no optimal incentives to follow an optimal activity level).

${ }^{34}$ In both cases the contribution of the victim to the accident risk is taken into account and the victim's claim on damages will be reduced wholly (contributory) or partially (comparative negligence).
}

underdeterrence. The tanker owner will consider the accident only as one where the limited amount of liability is the maximum damage that can be suffered and a corresponding (lower) level of preventive measures will be chosen. As such, a financial cap on liability can therefore be considered inefficient, more particularly since it concerns here a situation where damage is suffered by third parties so that Coasean bargaining is not possible.

A possible justification for the cap could be found in the situation where one would argue that the comparative negligence defence (just mentioned) would not provide adequate incentives to victims (more particularly the coastal states suffering the oil pollution damage). In that case one could argue that lower than full compensation for the victims may provide additional incentives for victim's care. However, given the fact that it is more important to control the injurer's incentives than the victim's and considering the fact that the CLC does provide for a comparative negligence defence, there is no reason to assume that this defence cannot adequately provide incentives for care to the victims of oil pollution damage. Moreover, the positive effects a cap may have on victim incentives would probably be totally countered by the negative effects this would have on the tanker owner's incentives for prevention.

However, the fact that, principally, a financial limit on liability as contained in the CLC should be considered inefficient does not necessarily mean that the cap will in practice also lead to a higher level of oil pollution incidents. First, for many (smaller) oil pollution incidents, the damage may well be lower than the limit on liability. The risk of underdeterrence may therefore only arise in those (catastrophic) cases where the amount of the damage actually was higher than the cap. Second, the prevention of oil pollution incidents is today primarily dependent upon regulation aiming at an optimal tanker design and at better training for the seafarers to prevent spill risks. Liability rules, therefore, have at most an additional deterrent effect to back up this regulation. The fact that the cap may create underdeterrence and thus may affect this additional incentive should not necessarily lead to an increase of pollution incidents. That will depend upon the effectiveness of the regulatory system and the extent to which liability rules provide supplementary incentives.

This argument has recently received serious support in a doctoral dissertation by Hay who argues that the regulatory system suffers from a serious enforcement deficit and that therefore more can be expected from an exposure of the tanker owner to full liability than from the regulatory regime [51]. In this respect Hay also relies on empirical US-based research, arguing that after the introduction of the Oil Pollution Act (OPA) in the US in 1990 the liability regime installed by OPA seems to have encouraged polluters to choose a level of precaution which minimizes pollution abatement costs whereas this literature is far more critical of the regulatory provisions of OPA, more particularly the double hull 
requirement [52]. ${ }^{35}$ This hence provides some support for the assumption in the economic literature that the financial cap may lead to underdeterrence, even in the presence of a regulatory system, which equally aims at the prevention of oil spills [51]. ${ }^{36}$

\subsubsection{Subsidy}

A second well-known effect of a limitation of liability, described in the economic literature, is that a financial cap will function as a subsidy. The tanker owner not being fully exposed to the costs of oil pollution damage in fact receives a financial advantage through the financial cap. This subsidy is primarily to the benefit of the tanker owner since the cap will result in lower insurance coverage costs. However, since these costs can be passed on to the cargo interests the oil industry will benefit from this subsidy as well. However, a part of the subsidy that benefits the oil industry is countered by the fact that the oil industry contributes to the International Oil Pollution Compensation Fund (referred to as the IOPC Fund, or the Fund). Oil receivers finance this fund by levies on the oil transported. The losers in this subsidized regime are obviously the victims to the extent that their damage is not compensated under the international regime (the CLC and the Fund).

Abolishing the financial limit on liability would of course lead to an increase in oil prices. However, the financial impact of the subsidy seems to be relatively low. Especially interesting in this respect is a study by Smets who analyzed in 1983 what the effects would be of an increase of the available amount of compensation by $\$ 250,000,000$ (compared to the limit of $\$ 52,000,000$ available at that time) [53]. Smets argues that the economic effects of such an increase would be limited as large oil spills are rare events compared with the total number of oil spills. $\mathrm{He}$ calculated that the economic impact of the mentioned increase would be less than $\$ 0.055$ per tonne transported and would thus be insignificant. The same conclusion was reached by the European Commission in the Erika proposals [54].

This leads to a few interesting conclusions. One of the distorting aspects of the subsidy constituted by the financial cap is inter alia the fact that the price of oil will be relatively too cheap. Relative in this respect means that the price of oil does not reflect correctly social costs and will therefore be relatively cheap, compared to other alternatives that would (by hypothesis) fully internalize social costs [55]. ${ }^{37}$ However, the quoted study by Smets shows that the nominal influence of even a serious increase of the compensation due on oil prices would be minimal.

\footnotetext{
${ }^{35}$ It is more particularly argued that the costs of the double hull requirements would outweigh the benefits.

${ }^{36} \mathrm{This}$ is also one of the conclusions of the dissertation by Hay [51], who therefore argues in favor of abolishing the caps.

${ }^{37}$ However, it should also be recognized that the subsidy of other energy resources may exist as well. In this respect, the overconsumption of oil energy may be counter-balanced to certain extent.
}

This can also be supported by the fact that since the entry into force of the Supplementary Fund Convention of 2003 (in 2005) an even larger amount of total compensation is available through the Supplementary Fund of almost one billion dollar. Although oil prices have significantly increased since then it may be clear that this is rather due to developments on the international market than to this legislative change. Even though therefore the nominal influence of abolishing the financial cap (or seriously increasing the limits) may be very small (and with that also the market distortive effects) this can at the same time be used as an argument to hold that the financial caps today are not justified any longer. It would apparently not have a devastating effect on the industry concerned.

\subsubsection{Undercompensation}

In serious cases the financial caps on liability can also lead to undercompensation of the victim. This problem of undercompensation can easily be shown by referring to the historical evolution which was sketched above (see Sections 3.3-3.5). Every time a new incident with higher damage occurred the limits were again increased since the then existing limits apparently did not suffice to provide compensation to accident victims [36]. In his thesis Julien Hay provides an overview of the amounts of damage caused by the largest tanker incidents in recent history [51]:

Given the amounts available at the time, these incidents could not be fully compensated. Today, through the entry into force of the Supplementary Fund Protocol on 3 March 2005, an amount is available of around 1000 million US Dollars. Hence, this may suffice to compensate today even most of the large oil spill incidents. However, history has shown that in the case of every new large incident the damage again was larger. ${ }^{38}$ It can therefore not be excluded that, notwithstanding all the recent changes, the current regime of the financial cap under the CLC combined with the supplementary fund, will not always be sufficient to provide full compensation in all cases.

Of course, one could argue that insufficient compensation to victims of oil pollution is not an economic consequence in the sense that whether or not a victim is compensated is primarily a distributional issue rather than an efficiency one. However, the type of catastrophic losses potentially caused by oil pollution incidents to an entire coastal region can be quite devastating for the affected area. It may affect prices of real estate and potentially even disrupt economic development in the particular sector and thus have consequences that go far beyond the mere direct victims of the oil pollution. Therefore, even from an economic perspective, an argument can be made that funds should be made available to compensate the losses and assist in restoration.

\footnotetext{
${ }^{38}$ Also due to the refinement of clean-up techniques and the related increase of costs.
} 


\section{A historical mistake?}

\subsection{Caps in a critical perspective}

From the economic analysis of financial caps for oil pollution damage presented in Section 5, it follows that the conclusions of much of the critical (legal and economic) literature presented in Section 4 can largely be upheld: there seems to be no justification for the introduction of financial caps for oil pollution damage where third parties are a victim. The question therefore arises why financial caps were introduced at all in the CLC in 1969. Limitation of the liability was, as a principle, hardly discussed during the 1969 conference preceding the CLC. Liability in maritime law had always been limited. The problem is, of course, that in traditional maritime law, limitation applies mainly in the contractual context towards a cargo owner. ${ }^{39}$ In that case the limit does not pose a specific problem since the limitation of liability can be compensated with a lower price for the transport. The cargo owner who expects higher losses could seek protection through first party insurance.

Although these arguments do not apply in the context of liability to third parties, the principle of limitation was hardly discussed. It was only mentioned (more particularly by the UK delegation) that a system of limitation of liability was justified by the mechanism of compulsory insurance [14]. That argument is, however, not very convincing since the duty to insure could have been limited to an (insurable) amount whereas the liability itself could have remained unlimited. Most of the discussions during the 1969 conference merely focused on the amount of the limit, not on the principle as such. Remarkable in that respect was that this amount was fixed on the basis of the tonnage of the ship, but the question was hardly asked whether the limited amount of compensation available would be sufficient to cover the actual costs of a (major) pollution incident [14]. ${ }^{40}$ The tonnage of the ship could indeed influence the scale of potential damage caused by it, but there are other factors that will also influence the pollution risk.

The basic problem seems to be related to the fact that the drafters of the convention were insufficiently aware of the fact that the limits in traditional maritime law apply in a contractual context where the potential victim stands in a Coasean bargaining situation with the injurer, whereas such a relationship between the tanker owner and the victim of oil pollution damage is usually lacking. The introduction of inefficient financial caps can probably be explained as a simple result of 'path dependency'

\footnotetext{
${ }^{39}$ The 1924 Limitation Convention mainly addressed damages suffered in the contractual sphere (to cargo interests). The subsequent Limitation Conventions (1976) were not explicitly limited to contractual damage, but their main focus was again on damage in the contractual sphere.

${ }^{40}$ Only the US delegation argued that the limit should be fixed in such a way that substantially all losses would be covered.
}

(Section 6.2) or perhaps (although not so clear) as the result of lobbying by interest groups (Section 6.3).

\subsection{Path dependency}

The fact that the drafters of the CLC simply introduced a limit on the financial liability of the tanker owner without much discussion may, from a theoretical perspective, be explained by the phenomenon known as "path dependency'. In simple terms, path dependency refers to the fact that choices made (in markets, but also by regulators) may to a large extent depend upon past decisions. Arthur argues that there is often a so-called 'lock-in by historical events' [56]. The basic insight is that initial action has put people on a path that cannot be left without some costs [57,58]. The literature moreover indicates that path dependency may to a large extent also explain why inefficient decisions are sometimes taken. The working of 'laissez faire markets' is that we can as a result of this path dependence stick on undesirable paths.

Although this notion of path dependency has been developed in the literature to explain why individuals sometimes choose inefficient decisions, its importance may not only be limited to market actions or choices of a particular technology. Also outside markets and more particularly when legislation is produced path dependency may play a role.

The model thus indeed has some appeal when addressing the coming into being of the financial caps for oil pollution damage. Section 2 showed that financial caps have (for good reasons) a long tradition in maritime law. Since the drafters of the CLC came also from this tradition it is in a way not surprising that at the 1969 diplomatic conference, which resulted in the CLC, the fact that the liability of the tanker owner should be capped was accepted without any discussion. Even when specific aspects of the limit were discussed, like the question under which circumstances the tanker owner could lose his limitation right (see Section 3.3.2), even in 1984 the drafters again relied on the 1976 LLMC. That convention, however, mainly applies to contractual claims in maritime law. Hence, there seems to be a strong appeal offered by existing regulations in maritime law which may explain why the financial caps and other features of maritime law were introduced in the international oil pollution regime without much discussion. It was apparently a path that may have been efficient in the contractual relationship traditionally envisaged by maritime law, but the dependency upon this path by the drafters may be the source of the resulting inefficiency when the same path was followed to determine the relationship between the tanker owner and third parties.

\subsection{Interest group analysis}

Whenever inefficiencies are discovered in a legislative regime, whether this is an international convention or in national law, scholars will point to the possible influence of 
interest groups which may explain these inefficiencies. The historical evolution as sketched above in Sections 2 and 3 makes clear that, even though detailed information is lacking, one can undoubtedly notice some influence of special interests. A starting point for the international regime was undoubtedly (see Section 3.2) the well-known Torrey Canyon incident which triggered the need for a legislative reaction. That can well fit into the theory of Rubin and Keenan concerning so-called 'shadow interest groups'. They argue that politicians may react to a shadow interest group, being a group that is not active yet but that may emerge as soon as a particular problem arises [59]. Potential victims of oil pollution damage could certainly be considered as members of such a shadow interest group. Once the accident occurs they could become active and hence one understands that politicians may ex ante wish to take their existence into account in regulation [60]. The coming into being of the 1969 CLC can only to some extent be explained by this shadow interest group theory. Indeed, the Torrey Canyon incident had already occurred and thus for those victims the benefits to be obtained from implementing the convention were real. However, the 1969 CLC did of course come into being not only for the victims of the Torrey Canyon, but for all other potential victims of oil pollution damage in the future. These can indeed be viewed as members of a shadow interest group.

Also, as far as the content of the convention and more particularly the financial cap is concerned, it is of course not difficult to argue that this may be the result of successful lobbying by the shipping industry. One can indeed clearly notice during the conference preceding the 1969 CLC that shipping nations were for obvious reasons lobbying in favor of low financial caps on liability whereas potential victims (coastal states) were opposing this and preferred higher limits. Nevertheless the CLC cannot be considered as the mere result of successful rent seeking $[61]^{41}$ by the shipping industry. The 1969 CLC/1971 Fund Convention regime may rather be the result of a workable balance between the competing interests. The ship-owning states defended different interests from coastal states which could be victimized by oil pollution and had less of a shipping interest. Moreover, a part of the financial burden is (as a result of the Fund Convention which provides for a financing by the oil industry) shifted to the oil receivers. Hence, from a public choice perspective, the international oil pollution regime (and some of its inefficiencies, such as the financial caps) could well be the result of a competition between different interest groups as predicted by Becker [62].

Moreover, the changes that took place after the original adoption of the conventions, more particularly through the 1992 Protocols, 2000 Amendments and 2003 Protocol

\footnotetext{
${ }^{41}$ Rent seeking is an economic notion which refers to the fact that powerful interest groups will lobby politicians to obtain legislation that grants them benefits (the so-called rents). See, generally, Buchanan et al. [61].
}

(see Sections 3.4 and 3.5) could well be explained as the result of changes in the balance of power between the various interest groups. The more accidents occurred, especially in western Europe and the larger the amount of damage was, the stronger coastal states like France and Spain became in their lobbying within the International Maritime Organization to increase the financial compensation to the victims. The result of this changing balance of power of course led to the most recent Supplementary Fund Protocol whereby today substantial amounts of compensation are provided through the fund even though the limits on the liability of the tanker owner are still kept in place [63]. ${ }^{42}$

\subsection{Policy conclusions}

The policy conclusions that can be drawn from this historical and economic analysis of financial caps for oil pollution damage are relatively clear and simple: the legal and economic scholars who always were critical of the financial caps on liability can be supported by this analysis. The historical analysis shows that financial caps for oil pollution damage were indeed 'a historical mistake'. The path dependency of the long tradition of financial caps in maritime law led to the inadvertence of copying this model of caps in a (mainly) contractual relationship to caps in a third party setting, with the resulting inefficiencies. The historical evolution itself clearly showed that the introduction of the financial caps was a mistake: after every new incident, with ever increasing damages, an adaptation of the convention limits was necessary. The result has been a cascade of protocols and amendments, whereby the international legislator always followed the new incidents. The normative conclusion at the policy level from this analysis seems therefore relatively straightforward: abolish the financial limit on the liability of the tanker owner for oil pollution damage since it was only based on the wrong assumption that the cap in traditional maritime law could also function well in the case of oil pollution damage, where third parties suffer losses.

\section{Concluding remarks}

This paper has addressed the well-known financial caps for oil pollution damage from an economic and a historical perspective. Using the economic analysis of accident law it is relatively easy to argue that financial caps on the liability for oil pollution damage are inefficient. This result had already been felt intuitively by some lawyers and economists. However, we attempted to add to this literature by analyzing the legal history of the coming into being of the

\footnotetext{
${ }^{42}$ This Supplementary Fund Protocol came into being as a result of pressure from the European Union to start its own supplementary fund. This, by the way, was introduced in Europe when France had the presidency of the European Council. Being a victim state France of course had a clear interest in such a European Compensation Fund.
} 
conventions. The question indeed arises why the international legislator who set up the 1969/1971 regime chose to introduce these financial caps on the liability of the tanker owner. Of course, intuitively, a law and economics scholar would argue that the caps were probably introduced to benefit the interest of industry, so that they can be considered as the result of successful rent seeking by the shipping industry.

The overview of the coming into being of the convention shows, however, that this explanation is too simple. Financial caps seem, as was shown in Section 2, rather to have a long tradition in maritime law. They were justified in maritime law as an attempt to balance the interests between the shipowner and the cargo owner. From an economic perspective a limitation of liability in this contractual relationship also makes sense since it provides the cargo owner with a possibility to secure his own protection (inter alia through insurance). Unlimited liability in the contractual relationship would lead to an undifferentiated increase of prices for all cargo owners, also for those who would not have a preference for this increased protection and would thus not have a willingness to pay the additional price. The limit on liability in the contractual relationship thus allows for a differentiation between the potential victims (cargo owners) taking into account their preferences and e.g. the quality of the cargo they were shipping and their attitude towards risks. In the absence of a limit on liability, relative prices would be too high and those expecting higher damage would be subsidized by those with lower potential damage. A limit on liability allows the cargo owner to obtain insurance protection in a differentiated way.

The historical overview makes clear that these justifications for the financial cap in the contractual setting were probably forgotten by the drafters of the CLC. A kind of 'path dependency' based on the long tradition of financial caps in maritime law led to the almost undebated acceptance of the financial caps at the 1969 conference preceding the CLC. The principle of the financial caps was not even debated at all, only the amount was. Hence, the caps may to a large extent be the result of such an inefficient path dependency, rather than the result of successful rent seeking by the shipping industry. Indeed, the international regime seems to be the result of a balancing of all the interests involved. In addition to the limited liability of the tanker owner, victims are also granted compensation through an international oil pollution compensation fund, subsidized by the oil industry.

Although today, as a result of many legislative changes, the amounts of available compensation for victims have substantially increased, still many inefficiencies exist. The most important one remains that the financial cap can lead to potential underdeterrence of tanker owners. Empirical research after the introduction of the American Oil Pollution Act showed the beneficial effects of the liability regime on prevention [55], which is confirmed by more recent research [51]. Therefore, the major argument in favor of the abolition of the financial cap is that the cap may lead to underdeterrence.

Of course, we realize that this analysis has several limitations. We could only focus on one aspect of the international oil pollution compensation regime, being the financial caps and we addressed those from an economic and historical perspective. However, a final judgment on the efficiency of the international regime will of course depend on other aspects, including the availability of insurance for the liability of the tanker owner and of the capacity of the insurer (the so-called Protection \& Indemnity Clubs) to monitor adequately preventive behavior of the tanker owner. Moreover, some will argue that the prevention of oil pollution should primarily be achieved through regulations, e.g. aiming at a better functioning of classification societies, port state control and phasing out of some single hull tankers.

Still, the supplementary deterrent function of liability rules, also in the context of oil pollution incidents, should not be underestimated, as was clearly stated in the (early) literature $[55,64,65]$. The fact that liability rules have apparently not been able to prevent major oil spill incidents can of course hardly be cited as evidence of an inadequate deterrent function of liability rules generally. Given the channelling of liability and the low limits, it is difficult for liability rules to exercise fully their desired preventive effect in the current legal context.

\section{References}

[1] Gauci G. Limitation of liability in maritime law: an anachronism? Marine Policy 1995;19:65-74.

[2] Selvig E. An introduction to the 1976 convention. In: The limitation of shipowner's liability - the new law. London: Sweet \& Maxwell London; 1986.

[3] Griggs P. Limitation of liability for maritime claims the search for international uniformity. Lloyd's Maritime and Commercial Law Quarterly 1997;369-76.

[4] Seward RC. The insurance viewpoint. In: The limitation of shipowners' liability - the new law. London: Sweet \& Maxwell London; 1986.

[5] Özçayir ZO. Liability for oil pollution and collisions. London: LLP; 1998.

[6] Xia C. Limitation of liability for maritime claims - a study of US law, Chinese law and international conventions. The Netherlands: Kluwer Law International; 2001.

[7] Donovan J. The origins and development of limitation of shipowners' liability. Tulane Law Review 1979;53:999-1045.

[8] Lord M. Ships are different—or are they? Lloyd's Maritime and Commercial Law Quarterly 1993;490-501.

[9] Wetterstein P. The principles of limitation and sharing of liability. In: Legislative approaches in maritime law, proceedings from the European colloquium on maritime law, 7-8 December 2000, Oslo; 2000. p. 95-100.

[10] Wang H. Shifts in governance in the international regime of maritime oil pollution compensation: a legal history perspective. In: Faure M, Verheij A, editors. Shifts in the compensation for environmental damage. Vienna: Springer; 2007. p. 197-241.

[11] Official records of the international legal conference on marine pollution damage 1969 (OR 1969), LEG/CONF/C.2/WP.2, p. 553-62.

[12] OR 1969, LEG/CONF/C.2/WP.35, p. 596-8.

[13] OR 1969, LEG/CONF/C.2/SR.17, p. 727-38. 
[14] OR 1969, LEG/CONF/4, p. 437-502.

[15] OR 1969, LEG/CONF/C.2/SR.8, p. 656-62.

[16] Official records of the international conference on liability and compensation for damage in connection with the carriage of certain substances by sea 1984 (OR 1984), vol. 2, LEG/CONF.6/C.2/SR.1, p. $311-26$.

[17] OR 1984, vol. 2, LEG/CONF.6/C.2/SR.6, p. 375-84.

[18] OR 1984, vol. 2, LEG/CONF.6/C.2/SR.8, p. 396-405.

[19] OR 1984, vol. 2, LEG/CONF.6/C.2/SR.5, p. 360-74.

[20] OR 1984, vol. 2, LEG/CONF.6/C.2/SR.7, p. 384-95.

[21] IOPC fund annual report 1988, IOPC Fund.

[22] De la Rue C, Anderson C. Shipping and the environment-law and practice. London: Lloyd's of London Press Ltd.; 1998

[23] OR 1984, vol. 2, LEG/CONF.6/WP.44, p. 310.

[24] OR 1984, vol. 2, LEG/CONF.6/SR.28, p. 610-9.

[25] OR 1984, vol.2, LEG/CONF.6/ SR.29, p. 621-2.

[26] OR 1984, vol.2, LEG/CONF.6/47, p. 51-6.

[27] Wu C. Pollution from the carriage of oil by sea-liability and compensation. London: Kluwer Law International; 1996.

[28] Vanheule B. Oil pollution: the international liability and compensation regime. European Transport Law 2003;38:550-4.

[29] Coghlin T. The convention on limitation of liability for maritime claims 1976. In: Mankabady S, editor. The international maritime organisation. London: Croom Helm; 1984. p. 234-51.

[30] Erika I, COM (2000) 142 final. Communication from the Commission to the European Parliament and the Council on the safety of the seaborne oil trading, 21 March 2000.

[31] Erika II, COM (2000) 802 final. Communication from the Commission to the European Parliament and the Council on a second set of community measures on maritime safety following the sinking of the oil tanker Erika, 6 December 2000.

[32] Rein A. International variations on concepts of limitation of liability. Tulane Law Review 1979;53:1259-76.

[33] Allen C. Limitation of liability. Journal of Maritime Law and Commerce 2000;31:263-80.

[34] Eyer W. Shipowners' limitation of liability — new directions for an old doctrine. Stanford Law Review 1964;16:370-93.

[35] Faure M, Wang H. Compensation for oil pollution damage: China versus the international regime. Asia-Pacific Journal of Environmental Law 2005;9:11-37.

[36] Faure M, Wang H. Economic analysis of compensation for oil pollution damage. Journal of Maritime Law and Commerce 2006;37: 179-217.

[37] Coase RA. The problem of social cost. Journal of Law and Economics 1960;3:1-44.

[38] See for an application of the Coase theorem to the issue of products liability Oi WY. The economics of product safety. Bell Journal of Economics 1973;4:3-28.

[39] Bishop W. The contract-tort boundary and the economics of insurance. Journal of Legal Studies 1983;12:241-66.

[40] Epstein RA. Product liability as an insurance market. Journal of Legal Studies 1985;14:645-69.

[41] Rea S. Non-pecuniary loss and breach of contract. Journal of Legal Studies 1982;11:50-2.

[42] Priest G. The current insurance crisis and modern tort law. Yale Law Journal 1987;96:1521-90.

[43] For an application to compensation for nonpecuniary losses see Faure M. Compensation of non-pecuniary loss: an economic perspective. In: Magnus U, Spier J, editors. European Tort Law,
Liber Amicorum for Helmut Koziol, Frankfurt am Main: Peter Lang; 2000. p. 143-59.

[44] For a summary of this literature see Shavell S. Economic analysis of accident law. Cambridge: Harvard University Press; 1987.

[45] Shavell S. Foundations of economic analysis of law. Cambridge: Harvard University Press; 2004.

[46] Shavell S. Strict liability versus negligence. Journal of Legal Studies 1980;9:1-25.

[47] Schafer HB, Schonenberger A. Strict liability versus negligence. In: Bouckaert B, De Geest G, editors. Encyclopaedia of law and economics, II: civil law and economics. Cheltenham: Edward Elgar; 2000. p. 597-624.

[48] For a discussion of the difference between both rules see e.g. Haddock D, Curran C. An economic theory of comparative negligence. Journal of Legal Studies 1985;14:49-73.

[49] Adams M. Warum kein ersatz von nichtvermogensschaden. In: Ott C, Schafer HB, editors. Allokationseffizienz in der rechtsordnung. Berlin: Springer; 1989. p. 214.

[50] Ott C, Schafer HB. Schmerzensgeld bei Korperverletzungen-Eine ökonomische Analyse. Juristenzeitung 1990;564-5.

[51] Hay J. Analyse economique du système international CLC/FIPOL comme instrument de prévention des Marées Noires. Thèse de doctorat, Université de Bretagne Occidentale, 19 September 2006.

[52] Ketkar KW. Protection of marine resources: the US Oil Pollution Act of 1990 and the future of the maritime industry. Marine Policy 1995;19:391-400.

[53] Smets H. The oil spill risk: economic assessment and compensation limit. Journal of Maritime Law and Commerce 1983;14:31-43.

[54] Wang H. The EU marine oil pollution regime-recent developments. European Environmental Law Review 2004;15:292-303.

[55] Wood L. An integrated international and domestic approach to civil liability for vessel-source oil pollution. Journal of Maritime Law and Commerce 1975;7:23-9.

[56] Arthur BW. Competing technologies, increasing deterrence, and lockin by historical events. Economic Journal 1989;97:642-65.

[57] Liebowitz SJ, Margolis SE. Path dependency lock-in and history. Journal of Law, Economics and Organisation 1995;11: $205-26$.

[58] Roe MJ. Chaos and evolution in law and economics. Harvard Law Review 1996;109:641-68.

[59] Keenan D, Rubin PH. Shadow interest groups and safety regulation. International Review of Law and Economics 1988;8:21-36.

[60] For a similar analysis to explain the emergence of the nuclear liability convention see Faure M, Van den Bergh R. Liability for nuclear accidents in Belgium from an interest group perspective. International Review of Law and Economics 1990;10:241-54.

[61] Buchanan J, Tollison R, Tullock G. Toward a theory of the rentseeking society. Texas: A and M University Press; 1980.

[62] Becker G. A theory of competition among pressure groups for political influence. Quarterly Journal of Economics 1983;371-400.

[63] Mason M. Civil liability for oil pollution damage: examining the evolving scope for environmental compensation in the international regime. Marine Policy 2003;27:1-12.

[64] Hunter LAW. The proposed international compensation fund for oil pollution damage. Journal of Maritime Law and Commerce 1972;4: $117-39$.

[65] Cummins PA, et al. Oil tanker pollution control — design criteria vs. effective liability assessment. Journal of Maritime Law and Commerce 1975;7:169-206. 